\title{
Las estatuas en la obra de Quevedo
}

\author{
Manuel Ángel Candelas Colodrón \\ Universidade de Vigo \\ Facultade de Filoloxía e Tradución \\ Departamento de Literatura española e Teoría da Literatura \\ Praza das Cantigas s/n, \\ 36300 Vigo \\ mcande@uvigo.es \\ [La Perinola, (Issn: 1138-6363), 22, 2018, pp. 65-82] \\ DOI: $10.15581 / 017.22 .65-82$
}

Fue loable costumbre de romanos y griegos alzar estatuas a los varones insignes en letras y armas, para no perder de vista las virtudes y hazañas con que ensalzaron la república y, por que todos pudiesen aprovecharse del ejemplo que dejaron a los venideros, ponían en la peana una breve inscripción y noticia de las letras que profesaron, de la religión y piedad que siguieron y de los hechos nobles con que grangearon la inmortalidad del nombre.

Así arranca la biografía de Quevedo de Pablo de Tarsia ${ }^{1}$. En ella se alude a la tradición de llenar el vestíbulo de las casas patricias con una colección de retratos y estatuas de los antepasados heroicos (imagines maiorum) para ejemplo moral de los presentes. Tarsia lo menciona como analogía de su propio ejercicio de biógrafo, ya que el relato de la vida de Quevedo adquiere esa doble dimensión de recuerdo o conservación del pasado (en una traslación ut sculptura poesis) y de ejemplaridad imitable para el presente. La biografía así se convierte en una forma de efigie o estatua destinada a sobrevivir al paso del tiempo. No es baladí la metáfora del abad de Conversano, ya que Quevedo, quizá no de un modo singular sino más bien guiado por una formación intelectual extendida, gusta de este motivo de la estatua como materia de sus poemas. En ocasiones lo coloca como tema central, como ocurre en los sonetos en forma de ékfrasis que celebran las figuras de personajes poderosos:

1. Tarsia, Vida de Francisco de Quevedo, fol. 1. En la dedicatoria a Pedro Aldrete, que antecede a la biografía, Tarsia recuerda a Valerio Máximo y explica la función del relato de la vida quevediana como cimagen delineada con los colores que ha podido alcanzar mi pluma» con el fin de colocarla en nicho, «en donde sirva de ejemplo a la posteridad, pues a este blanco tiraron los más nobles y más entendidos caballeros de la antigüedad en adelantar el uso comúnmente introducido de tener cada uno en lo más vistoso de su casa la memoria de sus mayores» (§3v). 
«Oh cuanta majestad, oh cuánto numen!» o «Más de bronce será que tu figura», dedicados a la estatua de Felipe III, o «Las selvas hizo navegar y el vientom, dedicado a la de Carlos V en Aranjuez ${ }^{2}$. En otras, de las que se ocupa este trabajo, la estatua es punto de partida o leit motiv para una reflexión de orden moral, con necesarias implicaciones políticas y, por añadidura tácita, de naturaleza doctrinal y religiosa, o, como en el caso que trataré al final, como recurso retórico para el desarrollo de conceptos admirables.

\section{Soberbia. Vanidad. Avaricia}

Es la estatuaria romana la principal fuente de inspiración moral quevediana. Los versos de la célebre silva «Roma antigua y moderna» pueden servir de ejemplo de cuál es la atmósfera urbana e iconográfica que Quevedo tiene en mente al respecto. El comienzo en forma de soneto es recreación, como se sabe, de la elegía 4,1 de Propercio ${ }^{3}$. En la parte central del largo poema que recorre la historia de Roma desde su fundación se repasa la tópica de ruinas, con la descripción de los estragos del tiempo, ejemplificada en los objetos abandonados de la urbe romana. Los trofeos, los blasones, los puentes, los arcos son reliquias del esplendor en la mirada del caminante, que fija sus ojos en las estatuas sin cabezas ni rostros, derrumbadas sobre la tierra. En esta pintura panorámica e incluso peripatética del ocaso imperial, el locutor poético destaca, además de «los dos rostros de Jano», los mármoles supervivientes del Capitolio:

Los que fueron palacios son ejemplos;

las peñas que vivieron

dura vida con almas imitadas,

que parece que fueron

por Deucalión tiradas,

no de ingeniosa mano adelgazadas,

son troncos lastimosos,

robados sin piedad de los curiosos.

Sólo en el Capitolio perdonaste

las estatuas y bultos que hallaste

y fue, en tu condición, gran cortesía,

bien que a tal majestad se le debía ${ }^{4}$.

Se pintan en este paisaje los anónimos cuerpos de las estatuas, esparcidos entre la hierba del foro, después de haber sido parte de los templos o de los pórticos. Dos son las estatuas que el hablante viajero

2. El análisis de estos sonetos requiere de un espacio específico, que desborda sin duda los límites que me he impuesto en este artículo.

3. Las notas de Rocha Sigler, 1994, explican con claridad las posibles fuentes de inspiración de esta silva.

4. Cito los textos de los poemas por Blecua, 1969. 
distingue: la ecuestre de Marco Aurelio, que preside la plaza concebida por Miguel Ángel como recordatorio de las glorias pasadas de la colina capitolina, y la de Mario, tal vez los Troffei di Mario, las dos estatuas, a ambos lados de la escalinata y cerca de las de los Dioscuros, trasladadas allá por Sixto III y que entre otras cosas se muestran decapitadas ${ }^{5}$ :

Allí delante vi el atrevimiento, pues Marco Aurelio en un caballo armado, el laurel en las sienes anudado, osa pasear el viento y en delgado camino y sendas puras hallan donde pisar las herraduras. De Mario vi y lloré desconocida la estatua a su fortuna merecida.

La voz poética no se detiene con el recuento de las imágenes de las lápidas o de los sepulcros que albergan a reyes, príncipes y emperadores que resisten el fragor de los años, sino que se apresura a extraer conclusiones de indudable ideario estoico: «El fuego examinó sus monarquías / y yacen, poco peso, en urnas frías, / y visten (ved la edad cuánto ha podido) / sus cuerpos polvo y su memoria olvido» (vv. 119122). La lección de las estatuas que se exhiben en el umbilicus mundi romano es evidente.

En otro de los poemas más conocidos de Quevedo, en el Sermón estoico, la descripción de la ciudad romana vuelve a constituir ejemplo moral de la soberbia humana, capaz de vulnerar las leyes de la naturaleza al atravesar los océanos (colocados por Dios como obstáculo para evitar la codicia de los hombres) en busca de riquezas con que adornar la urbe. Quevedo desvela el error en la ostentación de los monumentos: las estatuas son ejemplo de esa locura, interpretadas como una regresión del mito de Deucalión, traído de nuevo, en este caso sin citar, cuando el motivo de las esculturas de figuras humanas aparece:

Escollos y collados los vemos en los pórticos sombríos mintiendo fuerzas y doblando pechos aun promontorios sustentar los techos. Y el rústico linaje que fue de piedra dura vuelve otra vez viviente en escultura (vv. 216-222).

5. Martinengo, 2009, detalla los pormenores de la Roma que describe Quevedo (con particular atención a la apariencia del Campidoglio romano en la época en que Quevedo pudo conocerlo) y, sobre todo, se detiene en comentar la metáfora (en delgado camino y sendas puras» para referirse al modo «en corveta» del caballo de la estatua (pp. 274-276). 
Las similitudes con la silva anterior son notables, con la elegía de Propercio por medio:

Esta que miras grande Roma agora, huésped, fue yerba un tiempo, fue collado $[\ldots]$ Jove tronó sobre desnuda peña, donde se ven subir los chapiteles a sacarle los rayos de la mano (1-2, 9-11).

El texto de Propercio describe la transformación de la urbe romana desde el instante mismo de su fundación, cuando era apenas un espacio rodeado de siete colinas:

hoc, quodcumque uides, hospes, qua maxima Roma est, ante Phrygem Aenean collis et herba fuit; atque ubi Nauali stant sacra Palatia Phoebo, Euandri profugae concubuere boues. fictilibus creuere deis haec aurea templa, nec fuit opprobrio facta sine arte casa;

Tarpeiusque pater nuda de rupe tonabat, et Tiberis nostris aduena bubus erat .

El poema de Propercio es una exaltación del esplendor romano, pero también es un elogio del humilde y rústico pasado de su fundación. La comparación entre la Roma bucólica, entregada a los distintos cuidados de la naturaleza, con la edificación de suntuosos lugares de la polis se destina en el poeta elegíaco romano a la glorificación de toda su historia. Quevedo añade a ese relato encomiástico algunas dudas sobre el sentido moral de ese cambio. En la silva «Roma antigua y moderna», Quevedo describía tres procesos sucesivos en esa historia: el de su apogeo (que comparte con Propercio), el de su ocaso (que describe con las ruinas) y el de su resurrección bajo la autoridad de la Iglesia. La descripción del declive tiñe de acentos morales la descripción de su crecimiento como urbe: la conversión de las colinas y de la vegetación en pórticos, edificios y estatuas es vista por Quevedo como una contravención a la virtud de los antepasados primigenios.

Con estas redes textuales, Quevedo observa en la involución del mito de Deucalión el signo de la decadencia moral, casi como un acto evidente de soberbia: las piedras se convierten en seres humanos, pero es esta misma estirpe humana la que coloca las piedras (que imitan a los propios hombres) como signo máximo de soberbia. En el soneto "Ya te miro caer precipitado» se describe la imagen del rico bajo un pórtico lleno de estatuas, de indudable escenografía romana: «Ya te miro caer precipitado / y que en tus propias ruinas te confundes; / que

6. Cito por la edición de Tovar y Belfiore, 1963. 
en ti propio te rompes y te hundes, / entre tus chapiteles sepultado» (1-4). Esta visión censora se concentra aún más en el soneto «Pise no por desprecio por grandeza», con idéntica idea sobre la escultura como objetivo final de la codicia. El locutor poético concede éxito al avariento en su viaje en busca de riquezas que han de servir como material para sus estatuas: la ironía del yo poético prefiere, en clara formulación de la aurea mediocritas, el disfrute en una cabaña con un fuego escaso. Lo interesante se cifra en el primer terceto, donde el locutor poético entiende que las estatuas o las pinturas que representan a sus antepasados y que llenan el atrio de su casa con el propósito de conservar su memoria constituyen en último término el único objetivo de su avaricia: «el escultor a Deucalión imite, / cuando anime las piedras de su casa; / el pincel a los muertos resucite».

La fijación de Quevedo por el poder del oro, transformador subversivo de la vida humana, pero materia imprescindible en las estatuas, se ejemplifica de forma extraordinaria en otro soneto: «Este metal que resplandece ardiente». Basada en un pasaje extenso de Tertuliano, en el capítulo v,1 de su De habitu muliebris, la composición explica el proceso de depuración del oro de la tierra con la personificación del metal resplandeciente que abandona para siempre la tierra y el lugar donde se encuentra:

Aurum et argentum principes materiae cultus saecularis assint necesse est unde sunt, terra scilicet plane gloriosior, quoniam in maledictorum metallorum feralibus officinis poenali opere deplorata nomen terrae in igni reliquit, atque exinde de tormentis in ornamenta, de suppliciis in delicias, de ignominiis in honores, metalli refuga mutatur?

Este metal que resplandece ardiente

y tanta envidia en poco bulto encierra entre las llamas renunció a la tierra ya no conoce el risco por pariente.

Fundido ostenta brazo omnipotente horror que a la ciudad prestó la sierra descolorida paz, preciosa guerra, veneno de la aurora y del poniente (vv. 1-8).

Ese proceso de separación del mineral del oro, la fundición en el fuego y su posterior conversión en monedas («en dineros ásperos cortados»), tal y como lo plantea Tertuliano, lo recoge Quevedo con la misma tensión moral con que describe la transformación de una colina al lado del Tíber, apenas cubierta de rocas y árboles, en una espléndida construcción de templos o foros porticados con estatuas en la Roma gloriosa. Esta oposición léxica tierra / bulto o sierra / estatua del soneto quevediano, análoga a las anteriores entre escollos y collados con pórticos o chapiteles, presta concreción a esa deriva pecaminosa.

7. Tertuliano, Opera, p. 562. 
La posesión de estatuas como forma de exhibición vanidosa de riqueza muestra una variante de interés en el soneto «Lágrimas alquiladas del contento»: el añadido de que tal codicia conlleva sacrilegio. En este soneto, Quevedo recrea dos pasajes muy cercanos de la sátira 13 (129-134 y 147-154) de Juvenal, en los que se describen varias acciones reprobables: la primera, la de la hipocresía de las lágrimas del familiar que solo son sinceras cuando lloran la pérdida de dinero y, la segunda, el ansia sacrílega, nacida de la cupiditas, de limar o pulir el oro de las estatuas de los dioses y luego fundirlo («masa de tesoro») para fabricar con él monedas:

haec ibi si non sunt, minor exstat sacrilegus, qui radat inaurati femur Herculis et faciem ipsam

Neptuni, qui bratteolam de Castore ducat: an dubitet solitus totum conflare Tonantem? (vv. 149-152).

Los sacrosantos bultos adorados ven sus muslos raídos por el oro; sus barbas y cabellos, arrancados. Y el ser los dioses masa de tesoro los tiene al fuego y cuño condenados $\mathrm{y}$ al Tonante, fundido en cisne y toro.

En el texto de Juvenal, que sirve de inspiración al poema como señala el epígrafe, el personaje satirizado es uno más del catálogo de sacrílegos o de impíos que piden a los dioses favores materiales. Quevedo elige este en concreto porque la oposición entre la devoción íntima y el oro que cubre las estatuas de los dioses conforma una de sus ideas religiosas más repetidas ${ }^{8}$.

Si se reúnen todas estas composiciones se puede elaborar un completo $\mathrm{y}$, en cierto modo, coherente argumentario moral. El relato que construye Quevedo sobre las estatuas, como objeto de innecesaria posesión y ostentación inútil, se antoja ordenado de acuerdo a un pensamiento cerrado de naturaleza estoica. Ese relato sucede en los mismos escenarios que se describen en los textos de Propercio, Juvenal, Horacio o Persio, referentes de la poesía moral quevediana. La sátira

8. La falsa devoción, que no oculta del todo la codicia y que conduce a la idolatría, aparece en textos satíricos y en memoriales combativos. En La Fortuna con seso y la Hora de todos, así como en Execración por la fe católica, Quevedo aprovecha el pasaje bíblico de la estatua del becerro de Baal. Esa estatua, construida con el oro de las joyas de las mujeres que aguardan a Moisés, sirve para la censura de los judíos, acusados de idólatras y sacrílegos. En Execración dentro de un pasaje bien largo sobre el motivo se lee: «Bien claramente se ve que del oro que les da Dios hacen ídolos y que si le dan es sólo para hacer idolatrías, para hacer sacrilegios, para hacer dioses contra Dios, para burlar y dejar a Moisén, su caudillo» (Alonso, 2015, p. 346); en la Fortuna: «Allí adoramos nuestras joyas en el becerro y juró nuestra codicia por su deidad la semejanza de la niñez de las vacadas» (cuadro 39). Aunque con objetivo preciso de vituperio adversus iudaeos, estos textos permiten conectar con los que Quevedo dedica a la censura del rico romano preocupado por adornar de estatuas doradas el pórtico o el vestíbulo de sus casas. 
romana, en sentido genérico, o los discursos ocasionalmente satíricos encontrados en otros autores (Marcial o Petronio, entre otros) ofrecen a Quevedo imágenes, ideas o episodios, cuando no le sugieren además una semejante perspectiva censora y, según los casos, una similar entonación de voces.

Con esas lecturas, Quevedo parece obtener un cuadro minucioso de la mundanidad romana: en él la estatua es signo eminente de vana ostentación. Es evidente su función como magnificación de una identidad social. Su exhibición en los atrios familiares o en los pórticos de las casas patricias, como modo de consolidar la gens, estimula el acto soberbio de cruzar los mares y buscar en los territorios alejados los minerales para el lujo. Así lo escribe en Providencia de Dios:

al entendimiento humano sirve la tierra, ya pechera, tributándole el fruto de tan innumerables labores, o ya sosteniendo el peso de tantas ciudades, para cuya fábrica ve navegar sus cerros en pedazos y en cuyo ornamento ve en estatuas mentir vidas sus mármoles ${ }^{9}$.

No hace falta recordar la insistente advertencia horaciana (expuesta en español por fray Luis de León con análoga perseverancia) sobre la locura que supone la navegación, con execración incluso para el inventor de la primera de las embarcaciones. La historia de Roma, resumida en las composiciones quevedianas, se ejemplifica en ese pormenor simbólico del aumento del adorno escultórico, al lado de las enormes edificaciones o de los retratos en pintura de los antepasados. La proliferación de estatuas parece pervertir la propia naturaleza donde se ubican y alcanza casi siempre la categoría de apariencia vana. Para cerrar el relato, Quevedo agrega el pecado moral del avaricioso que incurre en sacrilegio, al despojar a los dioses de su oro para convertirlo en calderilla para comerciar.

\section{ESPEJO DE ACGIONES HUMANAS}

La impartición de lecciones morales no se limita a señalar el estrago del tiempo y, en consecuencia, la inutilidad soberbia de las ansias humanas. Las estatuas de los poderosos ofrecen a los demás espejos donde mirarse. En el arranque del Marco Bruto, Quevedo glosa las palabras de Plutarco sobre la estatua de bronce erigida a Junio Bruto en el Capitolio, entre las de los distintos reyes. Sobre la estatua del padre de Marco Bruto, Quevedo propone un sentido moral, con más de advertencia que de memoria:

Tenía Bruto estatua, mas la estatua no tenía Bruto, hasta que fue simulacro duplicado de Marco y de Junio. No pusieron los romanos aquel bulto en el Campidolio tanto para imagen de Junio Bruto como para consejo de bronce

9. Quevedo, Providencia de Dios, p. 15. 
de Marco Bruto. Fuera ociosa idolatría, si solo acordara de lo que hizo el muerto y no amonestara lo que debía hacer al vivo. Dichosa fue esta estatua, merecida del uno y obedecida del otro ${ }^{10}$.

En este ejercicio retórico de énfasis, Quevedo señala estas dos funciones de las estatuas: la de representación o figuración de un personaje, con la intención de conservar su memoria o de formar parte de los armaria familiares, y la de ejemplo para los que la contemplan. La estatua de Junio Bruto era solo una mera imagen de Junio Bruto. Pero no estaba Junio Bruto en ella: no poseía la capacidad aún de servir de aviso a su hijo Marco Bruto. Sólo cuando la estatua cumple su función ejemplar, la estatua es. En Quevedo, estas sutilezas escolásticas -que nacen del propio Aristóteles cuando explica los conceptos elementales de materia o de forma- entre la sustancia (la forma y la materia de la piedra) y su causa final (lo que pretende significar el bulto) permiten desarrollar en varias líneas su pensamiento. Más adelante, en este mismo texto del Marco Bruto, escribirá: «si Julio César leyera y no mirara a la estatua de Pompeyo, la temiera proceso y no la viera imagen: tuviérala por querella de bronce contra él y no por adorno de su tribunal ni lisonja de su venganza» (fol. 55-55v). En la distinción entre mirar y leer se halla la clave: las estatuas, a la manera de la pintura, son muta eloquentia, no sólo más o menos eficaz mímesis ${ }^{11}$.

En otro pasaje de su obra en prosa, en Doctrina estoica y a propósito del episodio referido por Plutarco sobre Anaxágoras y Nicocreonte, Quevedo se acerca a la materia estatuaria y a su condición de figura representativa con algo más de riesgo religioso. El propio Quevedo es consciente de ello, ya que comienza ese paso con una explícita solicitud de amparo eclesiástico. El pasaje trata la anécdota (similar a la del martirio de san Lorenzo) en la que Anaxágoras, torturado con martillazos de hierro, se jacta de que los golpes no causan daño en su cuerpo porque ya no se halla dentro de él. Quevedo añade que no solo no le causan dolor sino que son motivo de tormento al propio Nicocreonte que lo inflige: «aquí está el sabio en tormentos y no padece; aquí padece el tirano que atormenta). Quevedo prolonga esta idea con las metáforas tantas veces repetidas en su obra del cuerpo como vestido o recinto del alma. En este caso, responde a las palabras de Plutarco («si le abrasan, ¿no se queman?») en esta parte de la Doctrina estoica y afina la metáfora con la idea del cuerpo como estatua o como efigie de lo que contiene:

No se quema el Sabio que arde: quémase el vestido de su vida en el cuerpo, que no se puede negar es parte del hombre. Los tiranos queman la estatua de lo que no pueden quemar. Blasón mentiroso es suyo decir queman al que queman la estatua contra los sabios y los buenos; no pasa, digámoslo así, de la estatua su poder; a él no alcanza el fuego; está más allá

10. Quevedo, Vida de Marco Bruto, fols. 1v-2.

11. Sobre la dimensión retórica de estos pasajes léase Krabbenhoft, 1994, pp. 100-103. 
de las iras de los hombres; aquel solo pasa su castigo y sus hogueras más allá del cuerpo que puede quemar las almas. Queman la parte terrestre del Sabio, no al Sabio ${ }^{12}$.

El texto desarrolla un concepto audaz, pero es inevitable pensar en el procedimiento de la quema inquisitorial in effigie: el propio Quevedo se permite un poco más adelante una ligera broma, al traer la anécdota de un caballero francés que, «en tiempo del grande Enrique, huyóse por graves delitos a Turín, pasó los Alpes en las mayores nieves del invierno; supo después que le habían quemado la estatua el propio día que pasó los yelos de los Alpes y dijo: “en mi vida he tenido más frío que el día que me quemaron; esto que dice de su estatua el delincuente, dice con más verdad de su cuerpo el sabio" „13. Mezclar las bromas sobre la dudosa validez de una práctica penal inquisidora con las veras de la fortaleza de ánimo del sabio que resiste el martirio no deja de tener sus riesgos. En todo caso, puede sumarse a beneficio de inventario esta pequeña osadía a su particular uso de los recursos retóricos para causar la admiración o la sorpresa de sus lectores.

La consideración negativa de la estatua se expone en el poema «¿Miras este gigante corpulento» para execrar las vanas apariencias. La metáfora es la de la colosal figuración en cartón piedra del gigantón típico de las celebraciones religiosas de calle. Y la idea básica es la paradójica de mostrar que su grandeza esconde su misma debilidad. No está demasiado lejos de los poemas anteriores que mencionan la fragilidad incluso de las estatuas en piedra, destrozadas por el paso del tiempo. En este caso, la escultura intrínsecamente efímera constituye un ejemplo aún más nítido. Esa grandeza, además, adquiere en este soneto una dimensión política, al mencionar a los tiranos como correspondencia del muñeco gigantesco de papel, relleno con tosquedad de pajas y de telas y sustentado por un hombre que lo mueve, al son de la música, desde dentro: "por de dentro es trapos y fajina, / y un ganapán le sirve de cimiento: / con su alma vive y tiene movimiento / y adonde quiere su grandeza inclina». El vacío interior de este armazón ligero pide de inmediato una comparación de corte senequista: la de los tiranos que exhiben su soberbia, pero que esconden en sus adentros la perversión de sus actos:

Tales son las grandezas aparentes de la vana ilusión de los tiranos: fantásticas escorias eminentes. ¿Veslos arder en púrpura y sus manos, en diamantes y piedras diferentes?

12. Quevedo, Epicteto y Phocilides, fols. 16-17v. Los textos antes citados se hallan también en estas páginas.

13. Quevedo, Epicteto y Phocilides, fol. 17. 
Pues asco dentro son, tierra y gusanos (vv. 9-14).

Puede uno conformarse con una lectura general sobre esta metáfora y complacerse de paso con el oxymoron «fantásticas escorias eminentes» que la resuelve, pero no alcanzará a comprender la posible clave particular que quizá se halla tras la imagen de esta grandiosa estatua frágil: la que permite sospechar que en esa vanidad general del tirano se halla alguna alusión específica. No es descartable, por supuesto, la más evidente metáfora de los sepulcros blanqueados con la que san Pablo definió a los hipócritas y que en otro lugar de la obra quevediana -como en la descripción del licenciado calabrés de El alguacil endemoniado- aparece con mayor nitidez: incluso puede aducirse el título del soneto (siempre con la duda sobre su autoría) que parece limitarse a una execración de «la exterior apariencia con el examen interior y verdadero». Pero la mención a la púrpura y a los anillos de piedras preciosas que adornan la mano comunican el texto con una diatriba de orden político.

Próximo a este soneto en el Parnaso (apenas un soneto los separa) se halla otro poema, «¿Miras la faz que al orbe fue segunda», cuya similar estructura deíctica en el arranque ofrece tesis plausible para la censura del tirano. En este caso, el epígrafe es más preciso: «Desastre del valido que cayó aun en sus estatuas». El soneto es paráfrasis de un pasaje de la sátira décima de Juvenal en la que se recuerda la actitud del pueblo que olvida al tirano Sejano (valido del emperador Tiberio) cuando cae en desgracia.

\footnotetext{
descendunt statuae restemque secuntur, ipsas deinde rotas bigarum inpacta securis caedit et inmeritis franguntur crura caballis. iam strident ignes, iam follibus atque caminis ardet adoratum populo caput et crepat ingens Seianus, deinde ex facie toto orbe secunda fiunt urceoli, pelues, sartago, matellae. pone domi laurus, duc in Capitolia magnum cretatumque bouem: Seianus ducitur unco spectandus, gaudent omnes (vv. 58-67).
}

En la citada silva «Roma antigua y moderna» se hace mención a la práctica romana (la llamada damnatio memoriae) de cortar las cabezas y los rostros de las estatuas de los emperadores muertos (en especial, los que gobiernan en tiranía) para que no quede memoria de sus acciones. En este soneto Quevedo describe el asalto de la plebe, que derriba y arrastra con cuerdas la estatua de metal para llevarla al fuego y fundirla, para luego obtener de ella objetos para las tareas domésticas más elementales. La relación de objetos metálicos -«urceoli, pelves, sartago, matellae» en Juvenal; “calderas, sartenes y asadores» en Quevedo- en 
que se convierte la estatua de Sejano reduce a metáfora rebajadora la caída radical del poder político:

El rostro que adoraron en Seyano, despedazado en garfios, es testigo de la instabilidad del precio humano (vv. 9-11)

La muerte in effigie de Sejano pretende anular la memoria tras su muerte verdadera. Ars naturam vincit enseña la tópica sobre la capacidad de la creación artística de vencer a la muerte. Los rostros de las estatuas permiten el recuerdo: la eliminación de sus reliquias (como contrapunto al intenso valor de guardar la más mínima prenda del virtuoso) lo borra de la historia. Este es el castigo ulterior al de su propia muerte: el final de la misma fama. En otro soneto, «Falleció César fortunado y fuerte», Quevedo desarrolla esa misma idea, pero no es la turba de los hombres librados del tirano la que cercena la fama con la destrucción de la estatua, sino el propio tiempo. El verso tópico del epigrama de Ausonio sobre la lápida de una tumba en la que solo se conserva una letra, "mors etiam saxis marmoribusque venit» encierra la idea de que también para el mármol de las sepulturas hay un final. Los ecos de la sátira décima de Juvenal de nuevo aparece en Quevedo: «quandoquidem data sunt ipsis sepulchris» (146), «también para el sepulcro hay muerte». Es, sin duda, materia poética muy repetida en Quevedo la visión de la estatua en ruinas como ejemplo incluso de que para el recuerdo de la historia también puede haber un término.

\section{NABUCODONOSOR}

Quevedo encuentra en las estatuas de los cónsules, pretores o emperadores romanos material poético para la reflexión de naturaleza estoica sobre el poder destructor del tiempo y sobre la fragilidad de las pretensiones humanas, dentro de un marco político más o menos declarado. Pero no olvida traer de los textos bíblicos el conocido pasaje de la estatua que soñó Nabucodonosor, fabricada de oro, plata y bronce sobre piernas de hierro y pies de barro. No hay distinción a estos efectos de la lección política entre historia sacra y religiosa; en el Marco Bruto se halla el parangón entre el cónsul romano y el tirano bíblico:

hay quien pone la corona en la cabeza para quitar la cabeza con la corona. En la cabeza de la estatua de César fue su ruina una diadema; en los pies de la estatua de Nabuco, una guija: de pies a cabeza sois peligrosos. Doctrina son estas dos estatuas: honra añadida os enferma la cabeza, que sois vosotros; pequeño golpe de cosa pequeña os deshace los pies que son vuestros vasallos (fol. 37).

La continuidad moral entre los episodios testamentarios y las figuras históricas de la Roma antigua se preserva. Así se puede comprobar 
con mayor detalle en varias composiciones que la tradición editorial ha querido ubicar (no con decisión inmutable) en la poesía sacra; aunque más bien se trata de composiciones de notoria índole político-moral, no obstante la escenificación veterotestamentaria. Es el caso del soneto «Es la soberbia artífice engañoso» que González de Salas incluyó en la musa Polimnia y que apareció en la musa Urania de Las tres musas castellanas, con dos títulos distintos: A la soberbia, con el ejemplo de la estatua de Nabuco. Muestra que, estando derecha, fue peligrosa y, vuelta de arriba abajo, es segura en 1670, y Comparación de las fábricas de la soberbia con las de la humildad en 1648. Con versiones muy semejantes en contexto moral y en contexto religioso, el soneto recurre al exemplum de la estatua de oro y plata de Nabucodonosor del Libro de Daniel $(2,31-32)$ como figura paradigmática de la osadía humana.

\section{$P$}

No alcanzó el oro a ver desde la altura

la guija que rompió con ligereza,

el barro en quien fundó rica locura.

El que pusiere el barro en la cabeza,

y a los pies del metal la lumbre pura,

tendrá, si no hermosura, fortaleza (11, vv. 9-14).

$\mathrm{T}$

No alcanzó el oro a ver desde la altura

la guija que rompió con ligereza,

el barro que olvidó rica locura.

El que pusiere el barro en la cabeza,

y a los pies del metal la masa dura,

tendrá con hermosura fortaleza (11, vv. 9-14).

Ya en su primer libro de espejo de príncipes, Discurso de las privanzas, recuerda esta figura: «no permetían la estatua de Nabuco tampoco, tras tantos metales preciosos y fuertes, los pies de barro» ${ }^{14}$. En la Homilía a la Santísima Trinidad vuelve sobre la imagen conocida: «levantóse la soberbia estatua que vio Nabuco desde el lodo de sus pies por todos los metales hasta el oro y una guija que cayó de un monte, sin manos la derriba ${ }^{15}$. Y no falta la alusión en la Vida de san Pablo como exaltación de la conversión del apóstol, que de perseguidor de santos y de la iglesia pasó a «vaso de elección y doctor de las gentes» y «propagador del evangelio»:

Alistó una guija contra una estatua que desde el oro al hierro fortalecían todos los metales; otra contra el filisteo que se ostentó promontorio huma-

14. Díaz, 2000, p. 200.

15. Fernández Guerra, 1859, p. 354. 
no. La una tuvo victoria por los pies; la otra, por la cabeza, para advertir que de pies a cabeza acaba con las amenazas de la soberbia una china ${ }^{16}$.

En Providencia de Dios, en el tratado segundo, publicado entre las obras póstumas en 1720, se lee la advertencia del error moral de dejarse llevar por las aparentes riquezas, reducidas a sueño:

Miremos la estatua de Nabuco: lo fuerte y sólido puso en el tejado, haciendo de oro la cabeza y el barro en los cimientos, haciendo de él los pies. La Iglesia a los pies pone el oro y el polvo en la frente y sobre la cabeza y esto lo hace ne offendas ad lapidem pedem tuum, cuando una guija es sobrada munición contra los pies de aquel coloso que gastó el metal, el bronce y el hierro en lo que no había de ser combatido y dejó sin armas la flaqueza de su fortificación. Todos nuestros desvelos son este sueño de Nabucodonosor ${ }^{17}$.

Es en Virtud militante donde las posibles consideraciones políticas pueden ser examinadas a mejor luz; en el texto anterior, de tenor doctrinal, las cláusulas se dirigen al comportamiento humano en general, pero en este texto, con la soberbia como tema principal, la lección se mide en términos de poder:

No he dicho de qué es la soberbia y cuáles son sus miembros, mas haré que lo vean todos en la estatua de Nebucadnezar. Toda ella representaba monarchías y tiranías y poderíos que cayeron; representábalos todos con oro, plata, hierro y bronce, porque la cabeza y lo más principal de la soberbia es codicia y sed de tesoros (lo que siempre fue forzosa ruina del poder y de las monarchías. [...] Al contrario, la sancta Madre Iglesia, para fortalecernos en la cabeza, nos pone el lodo y nos manda poner el oro y la plata debajo de los pies ${ }^{18}$.

Idéntica materia se aprecia en el soneto «Las puertas del infierno siempre abiertas». La alusión contra tyrannos es explícita, si se toma como ajustado -y del propio Quevedo- el epígrafe que acompaña al texto: Amenaza a los tiranos que, fiados en los metales preciosos en que crecen, pretenden prevalecer contra la piedra sobre que fundó Cristo su Iglesia, con la similitud de la estatua de Nabuco. Basado en ese mismo episodio del libro tercero de Daniel, el soneto se presenta como una eficaz composición retórica de exaltación de la Iglesia. La estatua que imaginó Nabuco y explicó Daniel está construida con metales preciosos pero basada sobre barro frágil. La Iglesia, que aparece con las metáforas de la nave y de la piedra, está fundada sobre suelo más firme:

Las puertas del infierno siempre abiertas no prevalecerán contra la nave

16. Nider, 1994, p. 164.

17. Quevedo, Obras póstumas, p. 181.

18. Rey, 1985, p. 155. Mantengo la transcripción no modernizada de esta edición. 
y piedra, y iquieres tú contra su llave

que prevalezcan tus nefandas puertas? (vv. 1-4).

Las referencias a los célebres versículos del evangelio de san Mateo (16,18-19) en el que Jesús designa a Pedro como fundamento de la Iglesia ocupan ese cuarteto: "et ego dico tibi quia tu es Petrus et super hanc petram aedificabo ecclesiam meam et portae inferi non praevalebunt adversum eam et tibi dabo claves regni caelorum). En este contexto se añade la contraposición entre la firmeza de un edificio construido sobre una piedra y la frágil construcción de la esplendorosa estatua de Nabucodonosor, sustentada apenas sobre pies de barro: «la piedra derribó la estatua vana / no la estatua a la piedra vencedora». En términos simbólicos, Quevedo contrapone la ortodoxia católica representada por la piedra (Petrus) a la idolatría nacida del pecado capital de la soberbia, que permite enlazar al rey Nabucodonosor que osa contravenir las leyes divinas con las fuerzas del infierno.

La utilización de la estatua de Nabuco con este significado no es exclusiva de Quevedo: recorre buena parte de la predicación contemporánea a Quevedo. La exégesis del sueño de Nabucodonosor que hace Daniel en la Biblia se presta al uso argumentativo. Puede aducirse para ejemplificarlo la muy difundida Flos Sanctorum de Alonso de Villegas, en concreto en la cuarta parte, con el Discurso xxv para el sábado segundo de Cuaresma:

siendo aquellas diferencias de metales de la estatua diversos reinos y monarquías que en el mundo habían de suceder unos a otros, siendo siempre en disminución, comenzando en el mismo rey Nabucodonosor y su reino, que era la cabeza de oro de la estatua, hasta que viniendo otro último de hierro y barro (que declaran los Santos haber sido el estado y señorío de los romanos) que un tiempo fue fuerte como hierro y otro flaco como barro y débil, vino la piedra del monte que fue el hijo de Dios hecho hombre por cuya venida todas esas monarquías cesaron y la piedra se hizo un monte que fue el Cristianismo, que creció grandemente por la predicación de los apóstoles, cuyo estado permanece y permanecerá hasta que el mundo se acabe (fol. 81-81v).

El significado simbólico de los metales, de la piedra y el barro se desarrolla con claridad. La interpretación política también, aunque es el agustino Basilio Ponce de León quien procede con mayor explicitud:

Aquella estatua que vio Nabucodonosor, donde se representaba gran parte de las monarquías del mundo, que por la grandeza de sus imperios se alzaron con este nombre, aunque tenía la cabeza de oro y los pechos de plata, en fin se remataba en barro y a una estatua tan grande que al parecer había de estar más firme que una torre, una pequeña piedrecilla le da en los pies y la derriba, que esa flaqueza es la que se encierra en aquellas muestras de fortaleza y ese lodo es lo que encubre aquel oro y aquella plata que llevaba los ojos (p. 730). 
La soberbia del soberano, representada en una estatua de apariencia imponente y escasa firmeza, parece un topos, pues, de las homilías contrarreformistas. El añadido político aplicado a las monarquías, aunque implícito en la figura del rey Nabucodonosor, también se asegura en los textos predicatorios del siglo xvir. La contraposición con la fortaleza de la iglesia no es extraña a esta clase de literatura propagandística. Quevedo reúne todas estas ideas y las somete al cómputo de versos en estos dos sonetos que se mueven entre lo moral, lo político y lo religioso.

\section{Fryne. La estatua de Venus}

Una singularidad retórica permite a Quevedo desarrollar el motivo de la estatua a propósito de un episodio célebre: el de Fryne, una prostituta griega, que hizo construir una figura de Venus como agradecimiento a su protección en el oficio. Son dos los sonetos que dedica Quevedo a esta famosa meretriz de la antigüedad: «Si Venus hizo de oro a Fryne bella» y «Fryne, si el esplendor de tu riqueza», impresos por este orden en la edición de 1648: el primero, el de la advocación de la estatua a la diosa Venus; el segundo, a propósito de la decisión de Fryne de reconstruir las murallas de Tebas derrumbadas por Alejandro Magno con el dinero obtenido de su comercio carnal.

Ambos poemas comparten un concepto paradójico: en el segundo, la idea de que la debilidad moral, nacida del pecado de la lujuria, permite restituir lo que la fortitudo esencial del emperador griego destruye; en el primero, que es el que interesa, la contradicción aparente de mostrar que la estatua de Venus, cincelada en oro, fue construida gracias al dinero (el oro) conseguido con el sudor de la lascivia propia de la diosa del amor:

Si Venus hizo de oro a Fryne bella, en pago a Venus hizo de oro Fryne.

$$
[\ldots]
$$

Adore sus tesoros, si los huella, el desperdicio y tarde ya los gime: que tal castigo y penitencia oprime a quien abrasa femenil centella (vv. 1-2, 5-8)

Quevedo fija su atención no tanto en la figura de la prostituta, sino en la de los griegos que doblemente cometen pecado: primero el de la lujuria pagada y luego el de la adoración de la misma diosa que les llevó a esa misma lascivia, siempre observada con rasgos negativos.

Ambos episodios eran muy conocidos: Erasmo de Rotterdam los rememora en sus Apotegmas. El de la muralla en el libro octavo (33); el de la estatua en el libro tercero (58), en este caso con la referencia a Diógenes el cínico como narrador de la anécdota. No solo trae al recuerdo la dedicatoria a Venus de la estatua sino que se centra en la paradoja que supone que sean los propios griegos quienes adoren la causa de su perdición lujuriosa: 
Phryne meretrix Delphis Venerem aurean dicavit eam videns Diogenes, asscripsit elogium, ex Graecorum intemperantia. Arguebat enim Graecos supra modum libidini deditos esse, quod scortum e turpi quaestu tantum auri collegisset (fol. 122v).

Arde en metal precioso su blancura: veneren pues les cuesta seso y vidas los griegos su pecado y su locura.

El cartel que figura en la peana de la estatua, Ex Graecorum intemperantia, y que es traído a colación en el título del poema, es repetido con frecuencia en numerosos libros de facecias o de anécdotas de los siglos XVI y xvir. Quizá pueda uno reparar en lo que señala el Theatrum politicum del canónigo y profesor de Teología, Ambrosio Marliano, ya que fue libro muy leído y editado en el siglo xvir y que figuró en la bibliotheca quevediana, como aseguran Carlos Fernández y Sofía Simões en su trabajo sobre el inventario o catálogo de Quevedo ${ }^{19}$. En el capítulo viII de este peculiar espejo de príncipes, en el dedicado a la Continentia principis, se juntan precisamente los dos hechos asociados a la muliercula Phryne, que estaban separados en Erasmo, con reflexiones e incluso expresiones muy parecidas a las de Quevedo:

Ad hanc rem apprime facit quod refert Atheneus ait enim Phrinem, insigne illud, Graeciae scortum, tantas opes sui corporis evulgatione comparasse, ut civitatis Thebanae muros iam ab Alexandro Magno dirutos, propriis sumptibus restaurare potuerit quod a magistratu, ut sibi liceret, postulavit modo haec nota marmoreis tabulis inscriberetur. Alexander destruxit Phrine meretrix extruxit. O rem plane portentosam, ac pene incredibilem. Sed quot domos illam voraginem oportuit evertisse, quot familias expilasse, quot patrimonia exhausisse, tantas ut opes coacervaret, quo tantum ausa fuerit moliri? Sed quid? Nonne de eadem scribit Plutarchus eo impudentiae devenisse ut in templo Apollinis delphici statuam Veneris ex auro solido dedicare non erubuerit? hac addita inscriptione, Ex Graecorum intemperantia ${ }^{20}$.

Es indudable que estas referencias (con sólidos fundamentos) u otras semejantes, dada su difusión, ofrecieron a Quevedo recursos para

19. Fernández y Simões, 2011, p. 42.

20. Marliano, Theatrum politicum, p. 86. En la Ludrica Historia de Baltasar Bonifacio, de iucunda eruditione, como señala su título, y en el libro 2 capítulo 21 (Quaestu meretricio) también se presentan juntos ambos episodios: "Phryne Thespiensis eodem mercimonio tantum auri congessit, ut Delphis Venerem auream dicaverit, cui signo Diogenes adscripsit elogium: Ex Graecorum intemperantia. Tolerabile hoc esset, nisi muliercula cum Magno Alexandro gloriae cupiditate, ac pecuniae contemptu certasset: voluit enim Amphionios illos Thebarum muros instaurare, dum modo inscribere non prohibirevir: Alexander evertit Phryne restituits) (pp. 62-63). (Alexander destruxit, Phrine meretrix extruxit) o "Alexander evertit, Phryne restituit) son las sentencias epigramáticas que rememoran lo que dice Ateneo en el libro XIII (capítulo 60) de sus Deipnosophistas a propósito del cartel que la prostituta Fryne solicitaba poner en el muro si le permitían pagar la construcción del muro, siempre según información de Calístrato en su tratado sobre las cortesanas. En este mismo libro, en un pasaje anterior, Ateneo explica que Apeles tomó la figura de Fryne como modelo para la pintura de su Venus, al igual que Praxíteles, enamorado de ella, lo hizo para su Venus de Cnido. Para el particular sobre Ateneo, léase Plata, 1999. 
sus composiciones. Quevedo adornó el episodio de la estatua de Fryne con alusiones a Fidias, el famoso escultor griego, que, en las citas consultadas, no aparece como creador de la escultura venérea. No es posible averiguar si manejó un dato concreto al respecto. Probablemente no le interesaba la fidelidad a los hechos sino encarecer el valor material de la estatua (incluso con la participación del mismo Midas) para conseguir en el terceto final que la execración (con mucho de retoricismo) contra la locura del pecado fuese más convincente.

La inclinación quevediana por la pintura presenta pruebas concluyentes: la silva Al pincel, escrita con circunstancia más o menos definida de defender la nobleza del arte pictórico, permite esa certidumbre. No son tantas las de su afición por la escultura. Los lugares en los que expone al menos con brevedad su idea sobre la escultura son escasos: si acaso puede aducirse su madrigal amoroso sobre el Retrato de Lisi en mármol, «Un famoso escultor, oh Lisi esquiva», donde la idea de imitación, la de repetir con fidelidad el original vivo se exagera con la idea de que el escultor, al hacerla de dura piedra, retrató mejor que la naturaleza (que aparece también como escultora, en una vuelta tópica del natura magna ars) su ingratitud. En otros lugares (algunos ya vistos), y de soslayo, la idea de la mímesis prevalece, sin añadidos especulativos sobre la índole del arte.

La estatua figurada se coloca como motivo para la reflexión sobre varios aspectos de la conducta humana: la vanidad de su exhibición en lugares bien notorios, como forma de honrar a los antepasados o a los dioses, conduce, por un lado, a la soberbia de vulnerar las leyes divinas con el fin de buscar los materiales con que fabricarlas y, por otro, al sacrilegio de confundir la devoción sincera con una pretensión interesada de riquezas. Los espacios para la consideración moral son los de la Roma antigua, la pagana, tal vez sugerida por las fuentes literarias (la satura romana) que elige para sus composiciones. El Capitolio romano es el lugar preferido para tales reflexiones, con la adición obligada de lecciones políticas. La imitación en piedra de personajes poderosos permite mostrar el topos historia magistra vitae, pero las estatuas siempre aparecen condenadas al olvido o a la desaparición y como ejemplario de la inexorabilidad del mundo. Los gigantones de las fiestas construidos con maderas y papel piedra, vacíos por dentro, apenas movidos por un modesto hombrecillo, o la estatua de Nabucodonosor, construida con nobles minerales en sus partes altas y con el barro como sostén del conjunto, son metáforas (algunas casi lexicalizadas) de la fragilidad del poder. La Venus de Fryne es, en contexto más ligero, símbolo de las contradicciones morales que se advierten en la representación figurada. En todas ellas, Quevedo va más allá de la superficie del artificio y de la mímesis e intenta apuntar una especulación filosófica, religiosa, política y, en cualquier caso, moral sobre lo que representan o significan las estatuas. 


\section{Bibliografía}

Alonso Veloso, María José, (ed.), Francisco de Quevedo, Execración por la fe católica, Madrid, Castalia, 2015.

Ateneo, Athenaeus, Deipnosophistae, Kaibel, In Aedibus B.G. Teubneri. Lipsiae, 1887. (consultado en Perseus.tufts.edu, con la traducción al inglés de C.D. Young, 1854).

Blecua, José Manuel, (ed.), Francisco de Quevedo, Obra poética completa, Madrid, Castalia, 1969.

Díaz Martínez, Eva María, (ed.), Francisco de Quevedo, Discurso de las privanzas, Eunsa, Pamplona, 2000.

Erasmo de Rotterdam, Apophtegmatum libri octo, Amberes, Joannes Steelsius, 1540.

Fernández González, Carlos y Sofía Simões, «Nuevas aportaciones a la Biblioteca de Francisco de Quevedom, Manuscrit.Cao, 11, 2011, 54 pp.

Krabbenhoft, Kenneth, El precio de la cortesía. Retórica e innovación en Quevedo y Gracián, Salamanca, Universidad, 1994.

Marliano, Ambrosio, Theatrum politicum, Roma, Corbelleti, 1631.

Martinengo, Alessandro, “Los paisajes italianos de Quevedo», La Perinola, 13, 2009, pp. 263-280.

Nider, Valentina, (ed.), Francisco de Quevedo, La caída para levantarse, Pisa, Giardini, 1994.

Plata, Fernando, “Contribución al estudio de las fuentes de la poesía satírica de Quevedo: Ateneo, Berni y Owen», La Perinola, 3, 1999, pp. 225-247.

Ponce de León, Basilio, Primera parte de Discursos para todos los Evangelios de la Cuaresma, Madrid, Serrano de Vargas, 1605.

Quevedo, Francisco de, Epicteto y Phocilides en español con consonantes, Madrid, María de Quiñones / Pedro Coello, 1635.

Quevedo, Francisco de, Vida de Marco Bruto, Madrid, Díaz de la Carrera, 1644.

Quevedo, Francisco de, Providencia de Dios, Zaragoza, Pascual Bueno, 1700.

Quevedo, Francisco de, Obras póstumas, Madrid, Martínez de Casas, 1720.

Rey, Alfonso, (ed.), Francisco de Quevedo, Virtud militante, Santiago de Compostela, Universidad de Santiago de Compostela, 1985.

Tarsia, Pablo de, Vida de don Francisco de Quevedo, Madrid, Pablo del Val, 1663.

Tertuliano, Opera, (con comentarios y notas de Juan Luis de la Cerda), Paris, Michaelis Sonnii, 1624.

Tovar, Antonio y María Belfiore, (ed.), Propercio, Elegías, Madrid, csic, 1984 (offset de la de 1963).

Villegas, Alonso de, Flos sanctorum. Quarta parte. Discursos y sermones, Barcelona, Noel Baresson, 1593. 


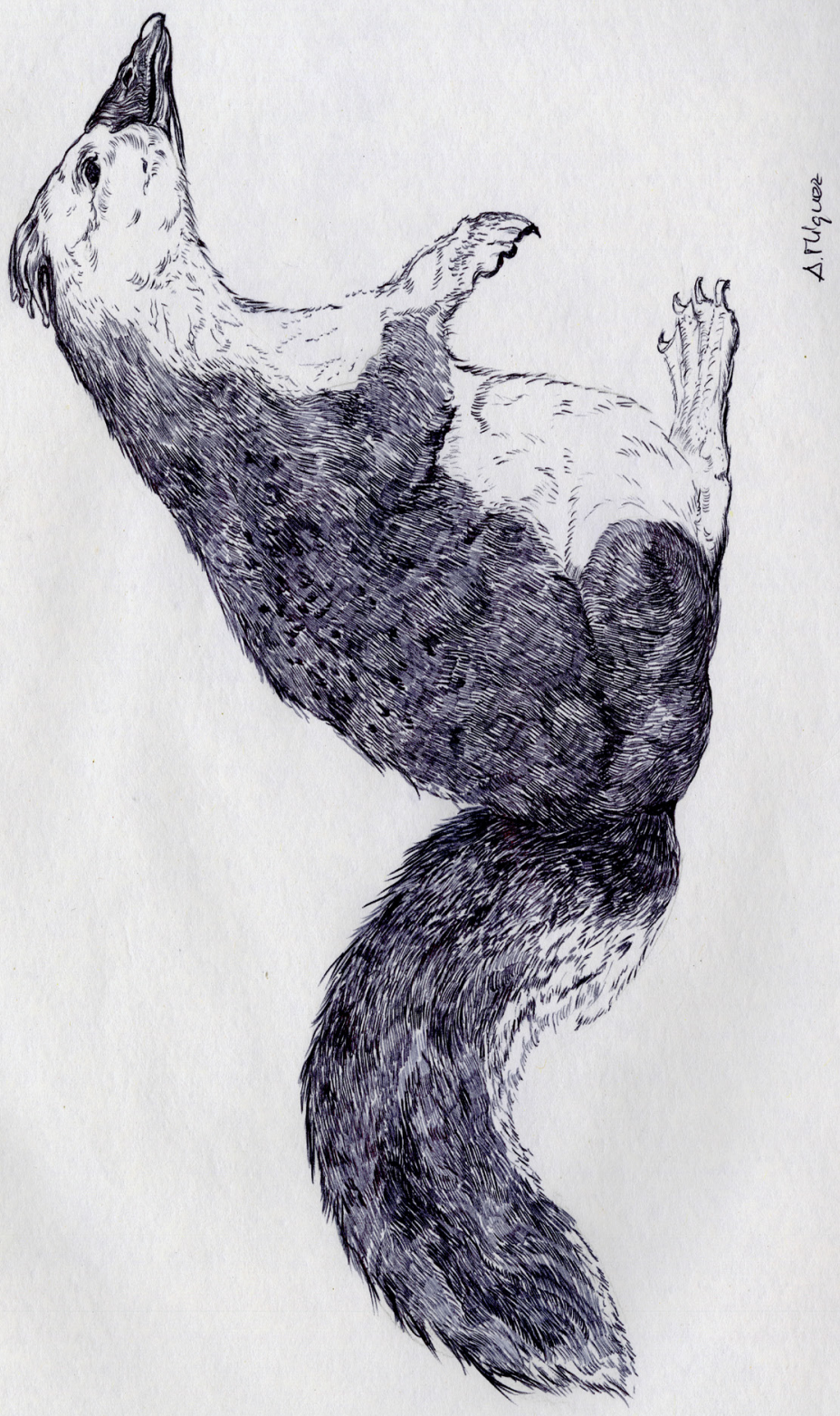


